\title{
Zika vaccine could be in production by year's end, says maker
}

\section{Owen Dyer}

Montreal

A vaccine against the Zika virus could be in production later this year, said a Canadian developer who previously led the effort to develop the ZMapp treatment for Ebola virus disease.

Gary Kobinger, head of vector design and immunotherapy in the special pathogens programme at Canada's National Microbiology Laboratory, told Reuters, "This vaccine is easy to produce. It could be cranked to very high levels in a really short time."

Kobinger's laboratory is collaborating with a team at the University of Pennsylvania led by David Weiner and with Inovio Pharmaceuticals and GeneOne Life Science of South Korea.

Inovio's chief executive, Joseph Kim, called Kobinger's timeline aggressive but possible. "I believe this will be the first to go into human testing. We believe we're ahead of the pack in the race for a Zika vaccine," he told Reuters.

Kobinger later told the Canadian Broadcasting Corporation that his prospective Zika vaccine was already in clinical production. He said, "We hope that all the testing, as in the past, will be acceptable to regulators like Health Canada and the FDA [US Food and Drug Administration], and we'll be able to start enrolling volunteers, with their approval, and start a stage 1 clinical trial by mid or late summer. That's a goal of course. We don't know if we can achieve it, but I think we can."

Asked when the vaccine might be available for use in humans, Kobinger replied, "Maybe by the fall. At least in 2016. It doesn't mean the vaccine is all of a sudden available for the entire population. The goal is to do our best but to be ready if there's an emergency."

Other groups working on Zika vaccines were less bullish about early prospects for a vaccine, noting the long timeline usually associated with vaccine development. Sanofi-Pasteur and GlaxoSmithKline have both been exploring the possibility of a Zika vaccine but warned that it would take several years to reach production. Sanofi-Pasteur's new dengue vaccine, approved last month, was 20 years in the making.
Anthony Fauci, head of the US National Institute for Allergy and Infectious Diseases, told NBC News that his agency was working on two vaccines but that it was likely that these would take three to five years to reach full production, though clinical testing might begin later this year. That schedule, unusually fast for a vaccine, was possible because one candidate was based on an existing vaccine against dengue and the other on a vaccine against West Nile virus, he said.

Brazil's president, Dilma Rousseff, this week rebuked the country's health minister, Marcelo Castro, for telling journalists that the country was "badly losing" the battle against the Aedes aegypti mosquito, even as 220000 military personnel led eradication efforts. Rousseff said that Brazil's Butantan Institute was working to develop a vaccine "in record time," but its director of clinical trials, Alexander Precioso, warned the BBC that a wait of three to five years was still likely.

For the moment, she said, the battle must focus on the mosquito. Brazil and the United States are examining approaches that involve the release of genetically modified male mosquitoes to interrupt reproduction.

Brazil's Supreme Court will hear a petition in late March to exempt women found to be carrying fetuses with microcephaly from the country's strict prohibition on abortion. An exemption already exists in the case of anencephaly.

Public Health England has warned men to wear condoms for a month after returning from any of the countries where the Zika virus is present, now numbering 23 and rising. Sexual transmission of Zika has been documented, ${ }^{1}$ and the virus has been isolated in sperm, ${ }^{2}$ though this is not believed to be a major factor in its spread.

1 Foy B, Kobylinski KC, Foy JLC, et al. Probable non-vector-borne transmission of Zika virus, Colorado, USA. Emerg Infect Dis May 2011, doi:10.3201/eid1705.101939. 2 Musso D, Roche C, Robin E et al. Potential sexual transmission of Zika virus. Emerg Infect Dis 21 Feb 2015, doi:10.3201/eid2102.141363. 